\title{
Metabolic Activity Interferometer: A Powerful Tool for Testing Antibiotics
}

\author{
Rachel R. P. Machado, ${ }^{1,2}$ Elton Soares de Lima Filho, ${ }^{3,4}$ \\ Rafael C. Dutra, ${ }^{5}$ Nádia R. Barbosa Raposo, ${ }^{6}$ Rafael S. Duarte, ${ }^{7}$ Geraldo Luiz G. Soares, ${ }^{8}$ \\ Bernhard Lesche, ${ }^{4}$ and Maria Auxiliadora C. Kaplan ${ }^{9}$
}

${ }^{1}$ Programa de Pós-Graduação em Biotecnologia Vegetal, Universidade Federal do Rio de Janeiro, 21941-901 Rio de Janeiro, RJ, Brazil

${ }^{2}$ Faculdade de Ciências Médicas e da Saúde (FCMS/SUPREMA), Km 796, Bairro Salvaterra, 36033-005 Juiz de Fora, MG, Brazil

${ }^{3}$ Département de Génie Physique, École Polytechnique de Montréal_L6902, Pavillon Lassonde, 2500, Chemin Polytechnique (S114), Montréal, (Québec), Canada H3T1J4

${ }^{4}$ Departamento de Física, Instituto de Ciências Exatas, Universidade Federal de Juiz de Fora, Rua Jose Lourenço Kelmer, s/n, Campus Universitário, São Pedro, 36036-900 Juiz de Fora, MG, Brazil

${ }^{5}$ Programa de Pós-Graduação em Farmacologia, Universidade Federal de Santa Catarina, Bloco D, CCB, Caixa Postal 476, Campus Universitário Trindade, 88049-900 Florianópolis, SC, Brazil

${ }^{6}$ Núcleo de Pesquisa e Inovação em Ciências da Saúde, Faculdade de Farmácia, Universidades Federal de Juiz de Fora, Rua Jose Lourenço Kelmer, s/n, Cidade Universitária, 36036-330 Juiz de Fora, MG, Brazil

${ }^{7}$ Laboratório de Micobactérias, Instituto de Microbiologia, Lab. 011, Bloco I, CCS, Universidade Federal do Rio de Janeiro, Cidade Universitária, 21945-970 Rio de Janeiro, RJ, Brazil

${ }^{8}$ Departamento de Botânica, Instituto de Biociências, Universidade Federal do Rio Grande do Sul, Avenida Bento Gonçalves, 9500-Bloco IV—Prédio 43433, 91509-900 Porto Alegre, RS, Brazil

${ }^{9}$ Núcleo de Pesquisa de Produtos Naturais, Universidade Federal do Rio de Janeiro, CCS, Bloco H, Cidade Universitária, 21945-970 Rio de Janeiro, RJ, Brazil

Correspondence should be addressed to

Bernhard Lesche, lesche@fisica.ufjf.br

Received 9 February 2012; Accepted 6 March 2012

Academic Editor: Yu-Lung Lo

Copyright (C) 2012 Rachel R. P. Machado et al. This is an open access article distributed under the Creative Commons Attribution License, which permits unrestricted use, distribution, and reproduction in any medium, provided the original work is properly cited.

It is demonstrated that the efficiency of antibiotics can be tested using an interferometric method. Two antibiotics were used as models to show that an interferometric method to monitor the metabolic activity of slowly growing bacteria can be a safer method to judge antimicrobial properties of substances than conventional methods. The susceptibility of Mycobacterium bovis to hexane extract of Pterodon emarginatus and to the well-known antibiotic rifampicin was tested with the interferometric method and with the conventional microplate method. The microplate method revealed a potential activity of hexane extract against $M$. bovis. However, the interferometric method showed that the action of this substance is rather limited. Also in the case of rifampicin, the interferometric method was able to detect resistant bacteria.

\section{Introduction}

Interferometric measurements of small changes of refractive index of bacterial culture medium can be used to monitor bacterial metabolic activity $[1,2]$. In a previous work [2], this method was described and a relation between the rate of index change and number of bacteria in the sample was established. The aim of the present work is to show that the interferometric method can be used to judge the efficiency of antibiotics.

The discovery of antibiotics seemed to be a definite solution for severe health problems such as tuberculosis. However, the appearance of resistant strains of bacteria destroyed this hope. New antibacterial substances have 
to be discovered and there is no guarantee that these new agents will not have the same destiny of becoming obsolete due to adaptation of the microorganisms by natural selection. The selection presupposes the survival of a specimen [3]. Therefore, the reliability of testing methods in studies of antibacterial activity is of crucial importance. Especially when unconventional substances, such as plant extracts, are investigated, a careful evaluation of methods is essential.

The majority of public health laboratories use the proportion method with Lowenstein-Jensen culture medium to obtain an antibiogram for mycobacteria. Many of the laboratories use this test, inoculating samples from the patient directly onto culture media with antibiotics in order to guide the treatment. For bacteria from the Mycobactezium tuberculosis complex, these tests take typically 3 months including the specimen collection [4].

There are several techniques that can detect the presence of mycobacteria in biological samples in a short period of time (approximately 10 days), and these methods also permit susceptibility tests with respect to commonly used drugs: Radiometric 460TB BACTEC system (measurement of $\mathrm{CO}_{2}$ production), nonradiometric systems BACTEC MGIT 960 (measurement of $\mathrm{O}_{2}$ consumption with fluorescence indicators), and $\mathrm{MB}$ (with a tetrazolium salt redox indicator), ESP Culture System II (pressure sensing), E-Test, Microplate Alamar Blue Assay (MABA), and microplates with resazurin $[5,6]$ or MTT (colorimetric assay) [7]. Recently, an interferometric method has been developed $[1,2]$. The metabolic activity interferometer (MAI) measures the refractive index change of the culture medium caused by bacterial metabolism (Brazilian Patent required: PI0301892-0 A2). The time derivative of the index change can be related to the number of active bacteria [2].

Susceptibility tests of mycobacterium to vegetal products are most frequently performed with the MABA method and microplates with resazurin or MTT $[8,9]$. This may be due to the lower cost of these methods. This restriction involves the risk of inadequate judgment of the activity of these unconventional substances. Vegetal products have naturally a high variability of composition, whereas conventional drugs have a known and reproducible chemical composition. Furthermore, there exist well established standards for tests of conventional substances available in the National Committee for Clinical Laboratory Standards (NCCLS). For this reason it is interesting to test susceptibility of mycobacterium to vegetal products with a precise quantitative method and to compare the results with the aforementioned redox methods.

The present work focuses on Pterodon emarginatus (Vogel). Medical use of P. emarginatus has attracted considerable attention in the literature stimulated by the folk treatment of several affections [10-12]. All parts of the plant are used.

P. emarginatus is a tree from the Brazilian cerrado (open pasture land) $[13,14]$. In the folk use it is known as "faveiro" or "sucupira-branca". Anti-inflammatory and antimicrobial activities of this plant have been demonstrated [12-17].
To our knowledge, tests of antibiotic activity of this plant with respect to mycobacterium have not been published so far.

In the present work, sensitivity tests of Mycobacterium bovis-BCG-Moreau/Rio de Janeiro to hexane extract of fruits from $P$. emarginatus, as well as to rifampicin, were performed. The conventional method using microplates with 96 wells with resazurin was compared with the interferometric method. The choice of hexane extract was motivated by the apolar nature of the compounds that are more likely to penetrate the lipidic cell wall of mycobacterium.

\section{Material and Methods}

2.1. Mycobacteria. The strain of Mycobacterium bovis used in this work was M. bovis-BCG-Moreau/Rio de Janeiro, the same that had been used in previous studies of the interferometric method [2]. The bacteria were spread on Lowenstein-Jensen culture medium, and 21 days afterwards colonies were harvested to form a suspension of turbidity equal to $1.0 \mathrm{McF}$ arland Standard. From this suspension a second one was prepared diluting the first one 1:20(v/v) in Middlebrook 7H9 broth (BD-lot.2112134-USA) enriched with Middlebrook OADC. This second suspension was used for both testing methods, the microplate method and the interferometric one.

2.2. Plant Material. Fruits of $P$. emarginatus containing seeds (Figure 1) were obtained from popular markets and compounding pharmacies in Juiz de For a-MG Brazil.

2.3. Preparation of the Hexane Extract. $30 \mathrm{~g}$ of the fruits, which contained seeds, were macerated. This material was subjected to extraction using a Soxhlet extractor during $24 \mathrm{~h}$ with hexane. Subsequently, the solvent was removed by rotary evaporation (R-114, Buchi-Switzerland). The collected extract was kept in amber glass at a temperature of $-20^{\circ} \mathrm{C}$. The preparations of solutions were made from this single stock.

2.4. Microplate Assays. The susceptibility tests in microplates with 96 wells and revelation with resazurin followed the procedure described in the literature [6]. All assays were realized in triplicates with at least 3 independent experiments performed in intervals of 21 days. A solution of $5000 \mu \mathrm{g} / \mathrm{mL}$ of the hexane extract was prepared by diluting the extract in dimethyl-sulfoxide (DMSO) and subsequently in sterile distilled water. The highest DMSO concentration in the wells was $10 \%$, and this concentration did not inhibit bacterial growth. The concentrations of the hexane extract were obtained by serial dilution in the wells with a constant dilution factor 2, using culture medium Middlebrook 7H9 (Difco) enriched with OADC (Becton-Dickinson). Subsequently, $100 \mu \mathrm{L}$ of the $1: 20$ suspension of mycobacteria was added to obtain a final concentration of $7.5 \times 10^{6} \mathrm{CFU} / \mathrm{mL}$ in the wells. The final concentrations of hexane extract were $1250 \mu \mathrm{g} / \mathrm{mL}, 625 \mu \mathrm{g} / \mathrm{mL}, 313 \mu \mathrm{g} / \mathrm{mL}, 156 \mu \mathrm{g} / \mathrm{mL}, 78 \mu \mathrm{g} / \mathrm{mL}$, 


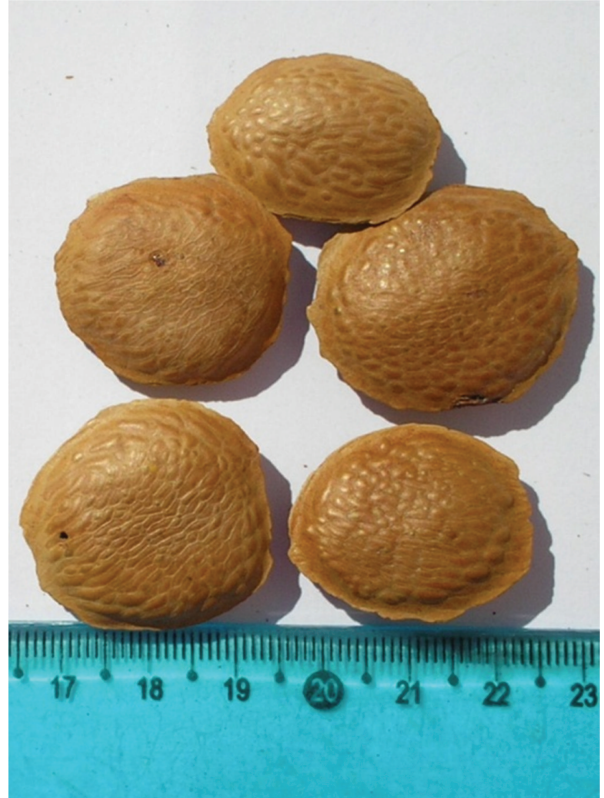

(a)

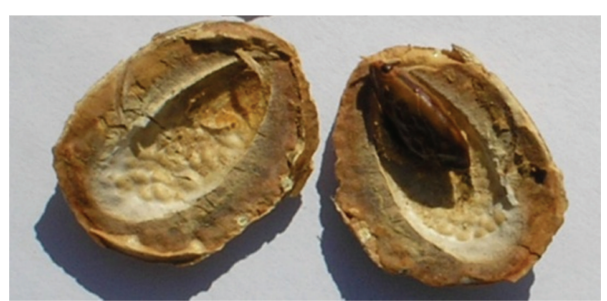

(b)

Figure 1: Pterodon emarginatus (Vogel) fruits with seed. The first picture shows the closed and the second one shows opened fruit with seed exposed.

$39 \mu \mathrm{g} / \mathrm{mL}$, and $0 \mu \mathrm{g} / \mathrm{mL}$ (control) and further $19.53 \mu \mathrm{g} / \mathrm{mL}$, $9.77 \mu \mathrm{g} / \mathrm{mL}$, and $4.88 \mu \mathrm{g} / \mathrm{mL}$ in two additional assays. The susceptibility of rifampicin (Lot 780773-SIGMA) was tested with 20 concentrations $32 \times 2^{-n} \mu \mathrm{g} / \mathrm{mL}$, with $n=0,1$, ..., 19, following the recommendations of NCCLS (2003). The inoculated microplates were kept at $37^{\circ} \mathrm{C}$ during 7 days. At the end of this period, $10 \mu \mathrm{L}$ of $0.01 \%$ resazurin solution (resazurin sodium salt powder from Acros Organic N.V., Geel, Belgium) was added to the wells, the readout was performed, and the minimal inhibitory concentrations (MIC) were determined.

2.5. Interferometric Assays. The apparatus used was the same one used in a previous work [2]. This machine contains sample holders with two wells each. One of the wells is filled with the bacteria containing sample and the other one with a reference solution that has exactly the same composition as the sample but without bacteria. Both wells have a sealed stock of air. The apparatus monitors the difference of the refractive index of the two solutions in each sample holder. This is done by positioning the samples periodically in a Michelson interferometer so that the sample and reference wells get positioned in the two arms of the interferometer (compare Figure 2).

The optical signal is read and analyzed automatically in real time. The temperature of the apparatus is kept at $37^{\circ} \mathrm{C}$ and maintained constant with precision of the order of one millikelvin.

The difference $\Delta n(t)=n_{\text {reference }}(t)-n_{\text {sample }}(t)$ is proportional to the amount of nutrients consumed by bacterial metabolisms. Under constant conditions, a uniform growing bacterial population typically results in a curve of exponential growth type:

$$
\Delta n(t)=A+B \exp \left\{-\frac{t}{\tau}\right\}
$$

For a given experimental result, the constants $A, B$, and $\tau$ can be determined using least square fit methods. The time constant $\tau$ is related to the time $\tau_{2}$ necessary to duplicate the population: $\tau_{2}=\tau \times \ln 2$. A determination of this constant can reveal characteristics of a bacterial population under given conditions.

As the samples in the MAI are hermetically sealed, no evaporation occurs, and the observation of samples can be extended up to months. Moreover, the interferometric technique permits one to accompany the development in real time, so that one can also observe the sample behavior during the 7-day period of the microplate assay, and the experimenter can determine the necessary duration of an experiment. Therefore the interferometric method is especially suited to test whether a antimicrobial substance is likely to permit selection of resistant strains.

The total number of samples that can be tested with our present machine is only 19. Therefore the concentrations tested were limited to five values (with 3 samples per concentration) and zero concentration (control, 4 samples). In the case of hexane extract of $P$. emarginatus the concentrations were zero, $29 \mu \mathrm{g} / \mathrm{mL}, 58 \mu \mathrm{g} / \mathrm{mL}$, $116 \mu \mathrm{g} / \mathrm{mL}, 232 \mu \mathrm{g} / \mathrm{mL}$, and $464 \mu \mathrm{g} / \mathrm{mL}$. The choice of these values was motivated by the results of microplate assay. $116 \mu \mathrm{g} / \mathrm{mL}$ was the mean value of encountered MICs. The rifampicin assay used zero, $2 \mathrm{ng} / \mathrm{mL}, 4 \mathrm{ng} / \mathrm{mL}, 250 \mathrm{ng} / \mathrm{mL}$, and $1000 \mathrm{ng} / \mathrm{mL}$. In a previous experiment, it had also been 


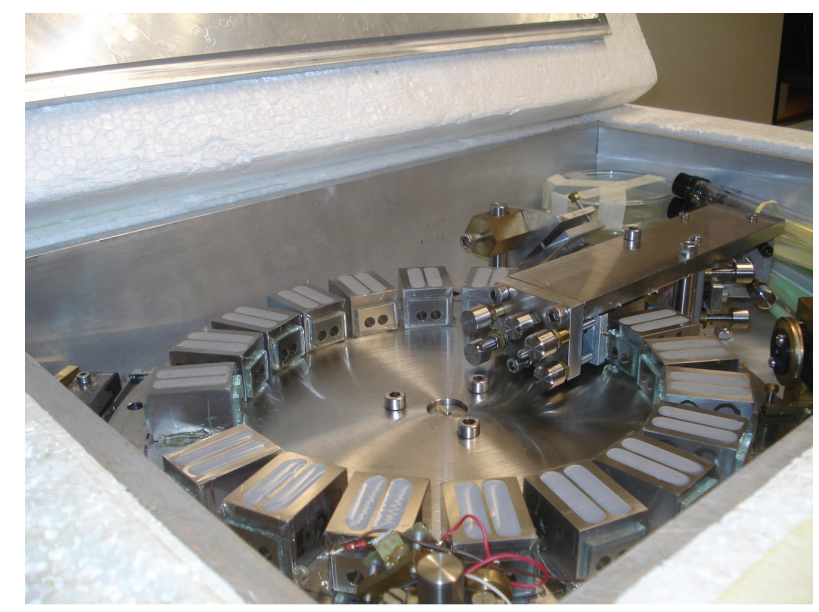

FIGURE 2: Metabolic activity interferometer with 19 samples.

tested that the DMSO did not alter the bacterial growth rates significantly.

\section{Results and Discussion}

The microplate test revealed that hexane extract of $P$. emarginatus has antibiotic activity against $M$. bovis-BCGMoreau/Rio de Janeiro. Table 1 shows results of six assays in temporal order.

It is evident that the hexane extract contains antibiotic components. However, the components of higher activity are less stable. These components seemed to be absent in the assays 3-6. The decay of these active components is not a simple matter of time. The extraction of the hexane extract occurred more than one year before the experiments started, and the time interval between the second and third assay was only 60 days. Therefore the decay has to be due to temperature changes and/or oxygen or light exposure of the stock of the hexane extract during preparation of solutions. On the other hand, the MIC value of $156 \mu \mathrm{g} / \mathrm{mL}$ was stable despite stock manipulations, and a one-year time interval was between the forth and sixth assay.

The microplate assays with rifampicin revealed a MIC of $4 \mathrm{ng} / \mathrm{mL}$. An exhaustive study of susceptibility of members of the $M$. tuberculosis complex against rifampicin and other compounds found MICs below $500 \mathrm{ng} / \mathrm{mL}$ [18]. In contrast to the results with hexane extract of $P$. emarginatus, the results of microplate assays with rifampicin were uniform.

The interferometric experiments showed that MIC values determined with microplate assays do not correspond to concentrations that guarantee safe extinction of the bacteria. Figures 3 and 4 show the curves of refractive index change of the $P$. emarginatus and rifampicin experiments, respectively.

In order to keep the graphs legible, only one curve per concentration is shown, with the exceptions of $c=$ $116 \mu \mathrm{g} / \mathrm{mL}, c=464 \mu \mathrm{g} / \mathrm{mL}$ (hexane extract) and $c=$ $1000 \mathrm{ng} / \mathrm{mL}$ (rifampicin), which had heterogeneous behaviors.
TABLE 1

\begin{tabular}{lcc}
\hline Assay & $\begin{array}{c}\text { Concentration } \\
\text { interval }[\mu \mathrm{g} / \mathrm{mL}]\end{array}$ & $\mathrm{MIC}[\mu \mathrm{g} / \mathrm{mL}]$ \\
\hline 1 & $39-1250$ & MIC $<39$ \\
2 & $4.88-39$ & $4.88<\mathrm{MIC}<19.53$ \\
3 & $4.88-39$ & No inhibition \\
4 & $39-1250$ & 156 \\
5 & $39-1250$ & 156 \\
6 & $39-1250$ & 156 \\
\hline
\end{tabular}

In Figure 3, the curves with $29 \mu \mathrm{g} / \mathrm{mL}$ and $58 \mu \mathrm{g} / \mathrm{mL}$ of hexane extract show practically the same behavior as the control samples. The three samples with $116 \mu \mathrm{g} / \mathrm{mL}$ of hexane extract show bacterial grow. This is compatible with the results of the microplate assays 4-6 (Table 1). One sample (A) behaved like the control samples, one (C) had an approximate 10 days retarded growth as compared to the control but with a smaller time constant $\left(\tau_{2}=3.5\right.$ days $)$ than the control ( $\tau_{2}=5.6$ days), and a third one (B) had a still bigger retardation and a larger time constant $\left(\tau_{2}=11\right.$ days $)$ (Table 2).

According to the assays in microplates, the samples with a concentration of $232 \mu \mathrm{g} / \mathrm{mL}$ of hexane extract of $P$. emarginatus should not exhibit bacterial growth. But the interferometric results clearly show bacterial growth in these samples. Only in two samples with $464 \mu \mathrm{g} / \mathrm{mL}$ of hexane extract no growth could be detected during the experiment. In the third sample of this concentration, an interesting retarded growth occurred. The time constant $\left(\tau_{2}=3.6\right.$ days) of this growing population was comparable with and even shorter than the time constants of the control curves. This retarded rapid growth can be explained by the hypothesis that the sample contained a small number of resistant bacteria at the beginning of the assay. From the time derivative of the curve at $t=39$ days and the time constant of the exponential behavior, one can estimate the initial number of resistant bacteria in that sample [2]. 


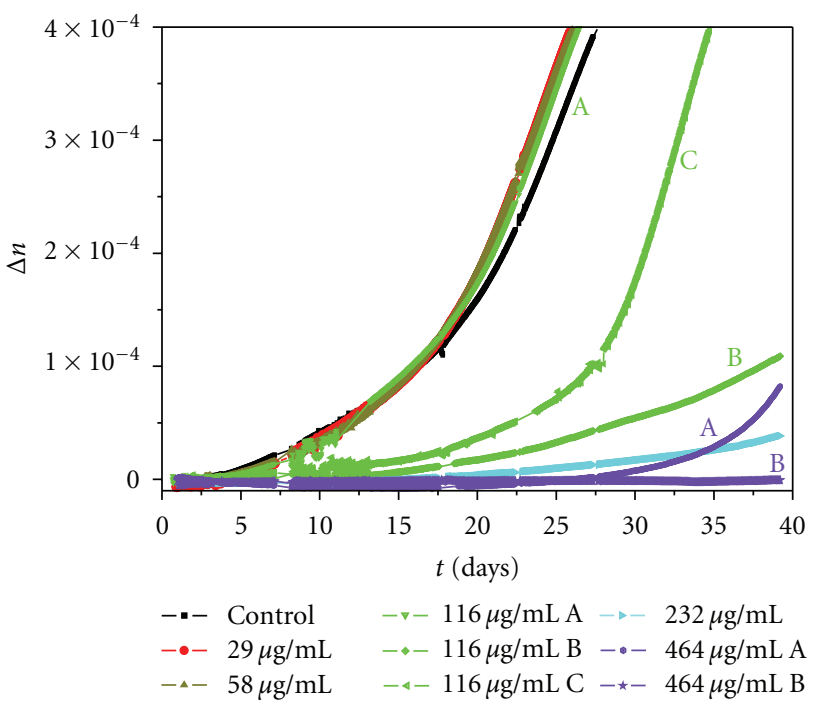

FIGURE 3: MAI result of the experiment with BCG and hexane extract of P. emarginatus. All curves refer to samples with BCG in 7H9 culture medium with OADC enrichment. Black: control (without hexane extract), red: $29 \mu \mathrm{g} / \mathrm{mL}$, dark yellow $=58 \mu \mathrm{g} / \mathrm{mL}, \mathrm{green} \mathrm{L}: 116 \mu \mathrm{g} / \mathrm{mL}, \mathrm{cyan}$ : $232 \mu \mathrm{g} / \mathrm{mL}$, and violet: $464 \mu \mathrm{g} / \mathrm{mL}$.

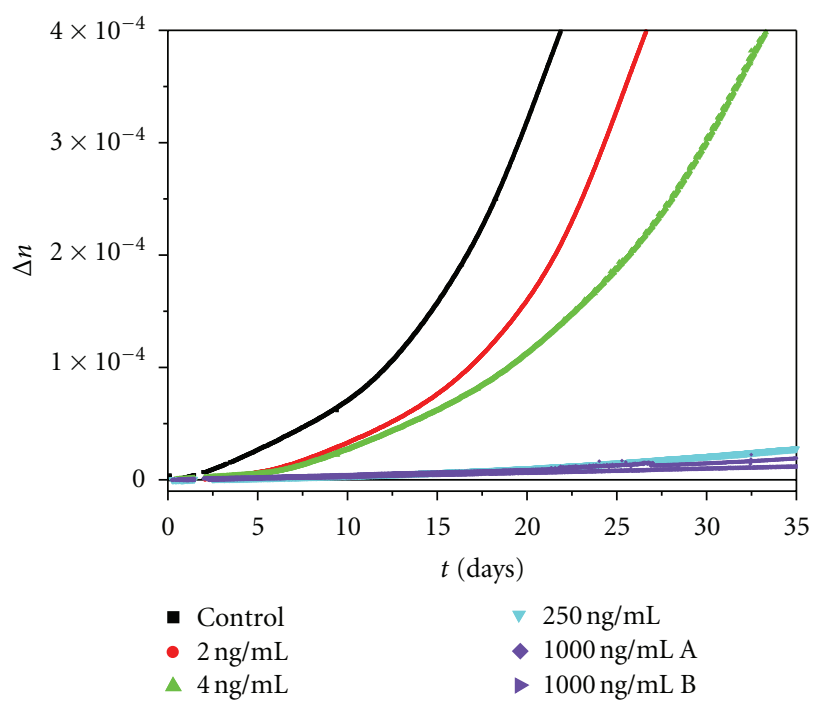

FIGURE 4: MAI result of the experiment with BCG and rifampicin. All curves refer to samples with BCG in 7H9 culture medium with OADC enrichment. Black: control (without rifampicin), red = $2 \mathrm{ng} / \mathrm{mL}$, green: $4 \mathrm{ng} / \mathrm{mL}$, cyan: $250 \mathrm{ng} / \mathrm{mL}$, and violet: $1000 \mathrm{ng} / \mathrm{mL}$.

The estimated number is $3 \times 10^{3}$. Including experimental uncertainty, the value could be between $6 \times 10^{2}$ and $1 \times$ $10^{4}$. If $3 \times 10^{3}$ resistant bacteria entered into the sample holder, one may wonder why the other two samples with the same concentration apparently did not have any resistant bacteria. In fact, if one inserts $1 \times 10^{6}$ randomly separated bacteria in a sample and gets $3 \times 10^{3}$ resistant ones, the probability of getting no resistant bacteria in a second and third equally prepared sample would be extremely small. However, it is a characteristic of mycobacterium to form entangled colonies, and the conventional preparation of samples by smashing colonies with glass beads and a vortex
TABLE 2

\begin{tabular}{lc}
\hline Sample & $\begin{array}{c}\text { Duplication time } \\
\text { [days] }\end{array}$ \\
\hline Control & $5.6 \pm 0.9$ \\
Hexane extract $P$. emarginatus $29 \mu \mathrm{g} / \mathrm{mL}$ & $5.4 \pm 0.3$ \\
Hexane extract $P$. emarginatus $58 \mu \mathrm{g} / \mathrm{mL}$ & $5.7 \pm 0.4$ \\
Hexane extract $P$. emarginatus $116 \mu \mathrm{g} / \mathrm{mL}$ A & $5.6 \pm 0.6$ \\
Hexane extract $P$. emarginatus $116 \mu \mathrm{g} / \mathrm{mL} \mathrm{B}$ & $11 \pm 1$ \\
Hexane extract $P$. emarginatus $116 \mu \mathrm{g} / \mathrm{mL}$ C & $3.5 \pm 0.3$ \\
Hexane extract $P$. emarginatus $232 \mu \mathrm{g} / \mathrm{mL}$ & $11 \pm 1$ \\
Hexane extract $P$. emarginatus $464 \mu \mathrm{g} / \mathrm{mL}$ A & $3.6 \pm 0.5$ \\
Hexane extract $P$. emarginatus $464 \mu \mathrm{g} / \mathrm{mL} \mathrm{B}$ & No growth detected \\
Rifampicin $2 \mathrm{ng} / \mathrm{mL}$ & $6 \pm 1$ \\
Rifampicin $4 \mathrm{ng} / \mathrm{mL}$ & $8.7 \pm 0.3$ \\
Rifampicin $250 \mathrm{ng} / \mathrm{mL}$ & $13 \pm 1$ \\
Rifampicin $1000 \mathrm{ng} / \mathrm{mL}$ A & $16 \pm 6$ \\
Rifampicin $1000 \mathrm{ng} / \mathrm{mL}$ B & No growth detected \\
\hline
\end{tabular}

mixer does not disjoint the colonies completely. Therefore, the sampling of $1 \times 10^{6}$ bacteria from a suspension does not correspond to a random selection of $1 \times 10^{6}$ independent elements. The $3 \times 10^{3}$ resistant bacteria that entered one of the sample holders may correspond to a single monoclonal colony.

Table 2 shows the time constants of bacterial growth. In the case of rifampicin, the phenomenological manifestation found was an increasing time constant of the exponential growth with increasing concentration of rifampicin. This behavior is compatible with the hypothesis that an increase of the antibiotic concentration corresponds to an increase of the number of molecules of RNApolimerase that got inactivated, 


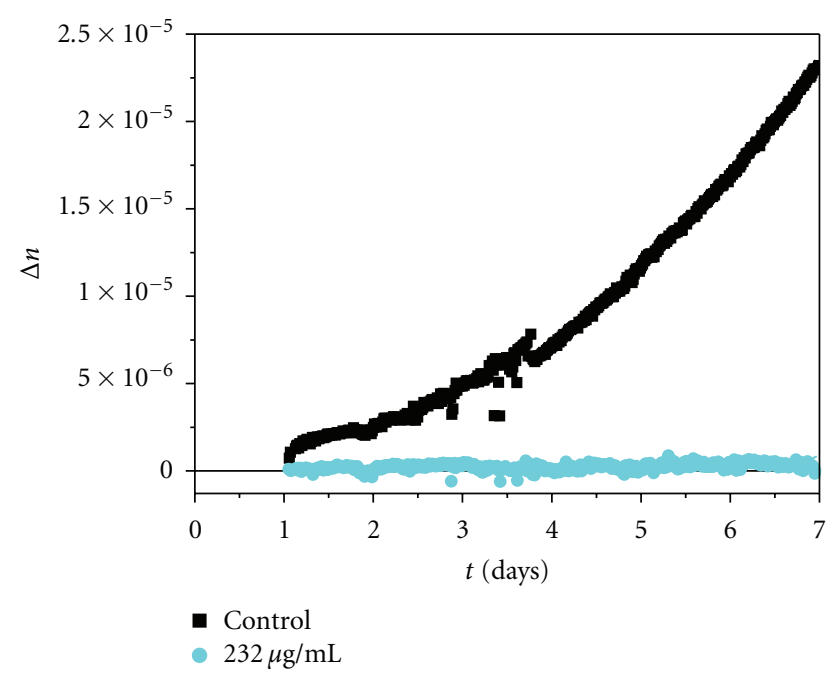

FIgURe 5: MAI result of two samples with BCG and hexane extract of $P$. emarginatus showing the time interval of $0-7$ days. Apparently there is no detectable metabolism in the sample with $232 \mu \mathrm{g} / \mathrm{mL}$ hexane extract.

which reduces the rate of vital protein synthesis reactions $[3,19]$.

The seven-day period used in the microplate assays is too short to detect the slow growth of mycobacterium under the influence of antibiotics. Figure 5 shows the control curve together with the curve of the $232 \mu \mathrm{g} / \mathrm{mL}$ hexane extract sample during the first seven days. Apparently, there is no detectable metabolism in the $232 \mu \mathrm{g} / \mathrm{mL}$ sample. But, as one can verify from Figure 3, this sample contains growing bacteria. The 7-day period in the usual microplate assays is especially limiting in the detection of resistant bacteria. Usually there are only a small number of resistant bacteria in a given sample, and during 7 days the number of bacteria grown remains undetectably small with present detection methods.

On the other hand, the microplate method is a simple and rapid method that may be very useful for scanning new substances. Furthermore, this method is useful to verify whether established properties of a bacterial stock are still valid. But this simple method should be accompanied by a quantitative method such as BACTEC or the interferometric method if the intention is the test of possible resistance.

According to Tosun et al. [20], compounds with a MIC value below $200 \mu \mathrm{g} / \mathrm{mL}$ in microplate assays can be considered potential candidates for antibiotic use. Considering the results in Table 1 , the hexane extract of $P$. emarginatus is a possible candidate. But the interferometric results reveal a less optimistic prospect.

\section{Conclusion}

The microplate method is a simple and cheap method especially suited for scanning potential antibiotic compounds. Its main efficiency is to indicate when a compound does not have antibiotic properties. It was found that the microplate method may not detect the presence of resistant bacteria in a sample due to the short period of time available and a limited sensitivity of bacterial growth detection. It was shown that the interferometric method permits monitoring samples quantitatively during long periods of time and can reveal the presence of bacterial resistance. Further this method permits determining the time constant of bacterial growth. On the other hand, the main limitation of our present interferometer (An interferometer with more sample places is currently under construction) is the small number of samples that can be examined in a single experiment. A larger number of samples may be admissible by expanding the present system, which is based of sample exchange, or by utilizing detector arrays. The main limitation of sensitivity in the present apparatus comes from perturbations of the fringe images due to optical obstacles such as dirt on windows or bacterial colonies. These perturbations influence the automatic fringe interpretation. In a future apparatus, the phase readout will be done without the use of fringe images. In conclusion, the most adequate procedure seems to associate the simple microplate method with the quantitative interferometric method to evaluate the real antimycobacterial effect of different compounds.

\section{Acknowledgments}

The authors thank the Fundação de Amparo a Pesquisa e Extensão de Minas Gerais (FAPEMIG) for the financial support (Process no. CEX-APQ-00246-10). The authors thank Marlei da Silva Gomes (Microbiology Institute CCSUFRJ) for the preparation of materials for microplate assays and Ruy Batista Santiago Neto (IFET Rio Pomba) for help in solving technical problems with the MAI. The authors thank Dr. Henrique Couto Teixeira and Dr. Ana Paula Ferreira (DPMI-UFJF) for the use of laboratory facilities and Michael Pinto dos Santos for the edition support.

\section{References}

[1] D. Faragó Jardim, R. Batista Santiago Neto, R. R. P. Machado, F. M. Aarestrup, J. P. R. F. De Mendonça, and B. Lesche, "Observing bacterial activity interferometrically," European Biophysics Journal, vol. 32, no. 2, pp. 159-162, 2003.

[2] R. R. P. Machado, E. S. Lima Filho, D. F. Jardim et al., "Metabolic activity interferometer: description and calibration of an interferometric method to measure growth of mycobacteria," European Biophysics Journal, vol. 38, no. 1, pp. 111-119, 2008.

[3] H. Goossens, M. F. Pharm, R. V. Stichele, and M. Elseviers, "Outpatient antibiotic use in Europe and association with resistance: a cross-national database study," The Lancet, vol. 365, pp. 579-587, 2005.

[4] World Health Organization, Anti-tuberculosis drug resistance in the world: the WHO/IUATLD global Project on antituberculosis drug resistance surveillance, WHO/TB/97.229, Switzerland; Geneva, 1997.

[5] A. M. Werneck Barreto, J. B. Melo Araujo, R. F. De Melo Medeiros, and P. C. De Souza Caldas, "Direct sensitivity test of the MB/BacT system," Memorias do Instituto Oswaldo Cruz, vol. 97, no. 2, pp. 263-264, 2002. 
[6] J. C. Palomino, A. Martin, M. Camacho, H. Guerra, J. Swings, and F. Portaels, "Resazurin microtiter assay plate: simple and inexpensive method for detection of drug resistance in Mycobacterium tuberculosis," Antimicrobial Agents and Chemotherapy, vol. 46, no. 8, pp. 2720-2722, 2002.

[7] L. Caviedes, J. Delgado, and R. H. Gilman, "Tetrazolium microplate assay as a rapid and inexpensive colorimetric method for determination of antibiotic susceptibility of Mycobacterium tuberculosis," Journal of Clinical Microbiology, vol. 40, no. 5, pp. 1873-1874, 2002.

[8] A. Martin, M. Camacho, F. Portaels, and J. C. Palomino, "Resazurin microtiter assay plate testing of mycobacterium tuberculosis susceptibilities to second-line drugs: rapid, simple, and inexpensive method," Antimicrobial Agents and Chemotherapy, vol. 47, no. 11, pp. 3616-3619, 2003.

[9] A. Martin, F. Portaels, and J. C. Palomino, "Colorimetric redox-indicator methods for the rapid detection of multidrug resistance in Mycobacterium tuberculosis: a systematic review and meta-analysis," Journal of Antimicrobial Chemotherapy, vol. 59, no. 2, pp. 175-183, 2007.

[10] J. C. T. Carvalho, J. A. A. Sertié, M. V. J. Barbosa et al., "Antiinflammatory activity of the crude extract from the fruits of Pterodon emarginatus Vog," Journal of Ethnopharmacology, vol. 64, no. 2, pp. 127-133, 1999.

[11] H. S. Falcão, I. O. Lima, V. L. Dos Santos et al., "Review of the plants with anti-inflammatory activity studied in Brazil," Revista Brasileira de Farmacognosia, vol. 15, no. 4, pp. 381-391, 2005.

[12] R. C. Dutra, M. B. Fava, C. C. S. Alves, A. P. Ferreira, and N. R. Barbosa, "Antiulcerogenic and anti-inflammatory activities of the essential oil from Pterodon emarginatus seeds," Journal of Pharmacy and Pharmacology, vol. 61, no. 2, pp. 243-250, 2009.

[13] M. E. Leite de Almeida and O. R. Gottlieb, "The chemistry of Brazilian Leguminosae, further isoflavones from Pterodon apparicia," Phytochemistry, vol. 14, no. 12, pp. 2716-2720, 1975.

[14] S. Barreira, J. R. S. Scolforo, S. A. Botelho, and J. M. Mello, "Estudo da estrutura da regeneração natural e da vegetação adulta de um cerrado senso stricto para fins de manejo florestal," Annals of Forest Science, vol. 61, pp. 64-78, 2002.

[15] J. C. T. Carvalho, Validação química-farmacológica da espécie vegetal Pterodon emarginatus Vog (atividade antiinflamatória), M.S. dissertation, Faculdade de Ciências Farmacêuticas, Universidade de São Paulo,, São Paulo, Brazil, 1998.

[16] K. G. L. Bustamante, A. D. L. Figueiredo, M. L. Soares et al., "Estudo farmacognóstico e avaliação da atividade antimicrobiana da casca de Pterodon emarginatus Vog. (Fabaceae)," in Congresso de Pesquisa, Ensino e Extensão da UFG-CONPEEX, 2, Goiânia, Brazil, 2005.

[17] R. C. Dutra, F. G. Braga, E. S. Coimbra, A. D. Silva, and N. R. Barbosa, "Atividades antimicrobiana e leishmanicida das sementes de Pterodon emerginatus Vogel," Revista Brasileira de Farmacognosia, vol. 19, no. 2A, pp. 429-435, 2009.

[18] N. Rastogi, K. S. Goh, M. Berchel, and A. Bryskier, "Activity of rifapentine and its metabolite 25-O-desacetylrifapentine compared with rifampicin and rifabutin against Mycobacterium tuberculosis, Mycobacterium africanum, Mycobacterium bovis and M. bovis BCG," Journal of Antimicrobial Chemotherapy, vol. 46, no. 4, pp. 565-570, 2000.

[19] N. Ritz, M. Tebruegge, T. G. Connell, A. Sievers, R. RobinsBrowne, and N. Curtis, "Susceptibility of Mycobacterium bovis BCG vaccine strains to antituberculous antibiotics," Antimicrobial Agents and Chemotherapy, vol. 53, no. 1, pp. 316-318, 2009.
[20] F. Tosun, C. A. Kizilay, B. Şener, M. Vural, and P. Palittapongarnpim, "Antimycobacterial screening of some Turkish plants," Journal of Ethnopharmacology, vol. 95, no. 2-3, pp. 273-275, 2004. 

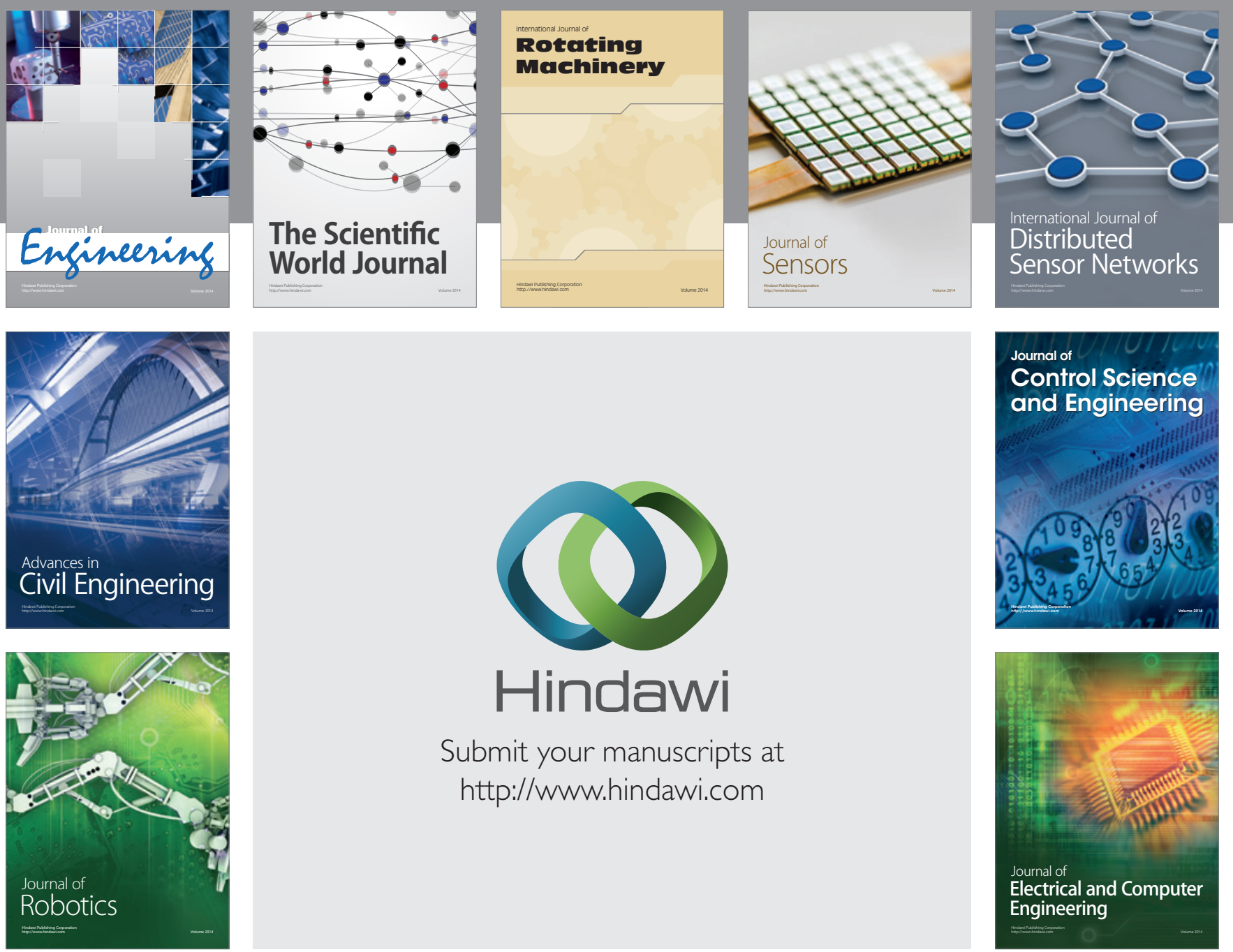

Submit your manuscripts at

http://www.hindawi.com
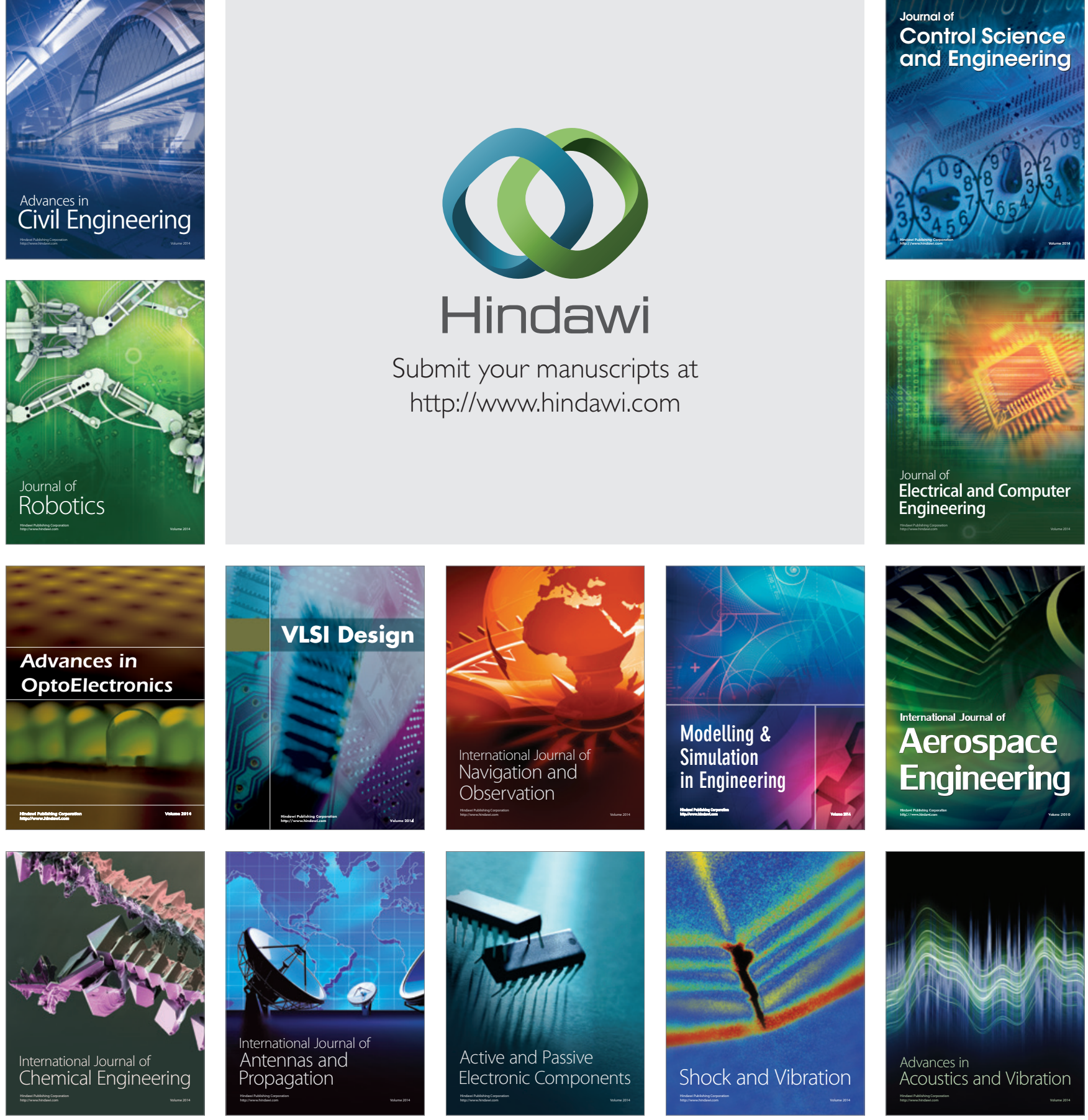